\title{
MILLENNIAL PERCEPTIONS OF SOCIAL MEDIA - REALITY VERSUS WHAT IS ACCEPTABLE
}

\author{
Sara Bliss Kiser, Alabama State University, skiser@alasu.edu \\ TammyL.Prater, Alabama State University,tprater@alasu.edu \\ Kimberly Johnson, Auburn University at Montgomery, kjohns36@aum.edu \\ Suzanne Smith, Presbyterian College, ssmith@presby.edu
}

\begin{abstract}
Today, everyone is connected with the use of smartphones and tablets. This research examines the thinking of millennials with regard to some of the different ways they connect, how they connect, and what are their beliefs about this interconnectedness. A survey gathered opinions about social media and what kinds of behavior are acceptable. The survey was administered to students at one private and two public institutions. These findings indicate that millennials still need guidance, which is provided, on what are acceptable uses of social media. Future research should be conducted to further the findings of this study as technology changes.
\end{abstract}

Keywords: Millennials, Social Media, Perceptions, Behavior

\section{INTRODUCTION}

In today's environment, one the largest demographics is the Millennial generation. They are ravenous users of social media and have their own varying thoughts on how to use social media, when to use social media, and how individuals should or should not be penalized for what they post on social media. Thus, the literature on millennial social media habits was reviewed. Then, research was conducted with millennials at three southern universities. Their habits and views are reported. Last, the paper suggests some directions for millennials and companies when it comes to their social media habits.

\section{LITERATURE REVEW}

The millennial generation includes those 16-35 years of age. This generation is considered one of the most diverse generations where fifty-six percent $(56 \%)$ are Caucasian, twenty-one percent $(21 \%)$ are Hispanic, thirteen percent (13\%) are Black, seven percent (7\%) are Asian, and three percent (3\%) are Other (Fry, Igielnik, \& Patten, 2018). They are the "digital natives" (Moran, 2016). When asked what makes their group "unique," twenty-four percent (24\%) say "Technology Use" because they believe it makes their lives easier (74 percent) (Nielsen, 2014). However, due to their being "plugged in" much of the time, a key stereotype is they do not listen (DeMers, 2017). Research has shown that eighty-five (85\%) to eighty-eight percent (88\%) are social media users (Pew Research Center, 2018). They are checking "in socially" between 20-21 hours a month and spending anywhere from six minutes to just over an hour a day when they visit the different social media platforms (Janicke-Bowles, Narayan, \& Seng, 2018; Nielsen, 2014).

Millennials are looking for self-gratification, at times, for what they do and say. The National Chamber Foundation (2012) found seventy percent (70\%) are "more excited about a decision they've made when friends agree" (p. 16). Thus, one positive use of social networking for millennials could be the ability to build social capital. Such sites "boost young people's social capital because their identities are shaped by what they share about themselves and, in turn, what others share and say about them" (Bolton et al., 2013, "Beneficial effects," para. 1) along with the number of likes they are receiving (Janicke-Bowles et al., 2018).

Over fifty percent (50\%) said they would not apply at a company which would not allow access to social media and approximately thirty percent (30\%) said it is acceptable to "share opinions about their work on social media" (Miller et al., 2013, para. 3). These are considered your "active social networkers" who "spend at least 30 percent of their 


\section{Issues in Information Systems \\ Volume 20, Issue 4, pp. 157-166, 2019}

workday linked up to one or more social networks" (Ethics Resource Center [ERC], 2014). Overall, millennials waste two hours a day at work compared to 41 minutes for Baby Boomers and 1.6 hours for Gen X'ers. The number one thing they waste time on is the Internet (Warner, 2013). All of this leads to lower productivity and efficiency as noted in one study that found 51 percent of workers believed this; however, millennials believed if the work got done, "it doesn't matter" (Warner, para. 12). This is similar to presenteeism, when the employee is physically there but not mentally there or just not productively working on company work. This could be due to the employee being sick, working on personal items, or being on their phone and/or internet (Prater \& Smith, 2011).

Of the active social networkers, sixty percent $(60 \%)$ said they would comment on their company if it was in the news, fifty-three percent (53\%) said they comment on work projects weekly, and more than thirty-three percent (33\%) say they comment on managers, co-workers, and clients on their personal sites (ERC, 2014; Verschoor, 2013). The lines will continually blur in this area. As noted by Carol Sampson, director of Foundations Human Resource Consulting, "the rules governing behavior on social media are vague ... and ever-changing, just as social media is changing. ...[it] is impossible to manage" (Bell, 2018, New Frontiers, para. 2). The ERC research also found millennials felt the following were acceptable: using social networking to find out about their competitors, "friending" a client or customer, keeping copies of confidential documents, blogging or tweeting negative comments about their company, and taking copies of work software home to load on their personal computers (Hull, 2012; Verschoor, 2013). On the other hand, millennials agree their companies need to communicate via social networking to build better relationships (Bolton et al., 2013). Social networking is seen as a missed opportunity as most active social networkers believe this form of communication could build trust (55 percent), and inform and educate (54 percent) (Bolton et al, 2013; York, 2017). However, as companies move to use social networks more, it also means they use it as a means to see what current and prospective candidates are doing and saying.

In turn, some millennials are modifying their use of social media. Whether due to age, the news, or listening to mentors, more millennials are now concerned about privacy issues (52\%) and removing content (37\%). Those that do chose to share content on sites, such as Twitter and Facebook, are more conscious in reviewing their privacy settings and removing content (60\% and 47\%, respectively) (American Press Institute, 2015). However, while one study showed twenty-six percent (26\%) of millennials say they have stopped using some of their social networks other studies show they tend to be less concerned about the government and others having access to their information (Cohen, Fowler, Medencia, and Rogowski, 2018). As social media is a growing part of everyday life, it is important to understand some basic rules of engagement.

\section{Negative Actions Lead To Negative Consequences - User Beware}

Employers today are increasing their use of publicly available information that can be mined on both employees and prospects. Such data mining can be a double-edged sword as many millennials admit "they do not present an authentic persona online, but rather have "highly socially desirable identities individuals aspire to have offline but have not yet been able to embody for one reason or another" (McCorkindale, DiStaso, \& Sisco, 2013, p. 71). Research has noted that most millennials have embarrassing content on at least one of these sites.

Meanwhile, employers frown upon negative posts about themselves or posts which may make their organization "look bad." Let's look at one "standout" example. In 2012, after the president of Chick-fil-A took a stance against gay marriage, Adam Smith, then CFO for Vante, drove through the drive through, got his free water, and berated the cashier about how Chick-fil-A was a "hateful corporation" (Peterson, 2015, para. 3). His mistake was putting his rant on YouTube. The video went viral and he lost his $\$ 200,000$ a year job. The CEO of Vante said, “... We expect employees to behave in a professional manner that's commensurate with their positions, and discuss their opinions in a civil fashion.... We thought what he did was inappropriate" (Broderick, 2012, para. 1). Smith found another CFO position relatively quickly, but then was summarily fired, after two weeks, when the CEO found out about the video (Diaz \& Effron, 2015).

Individuals simply do not seem to understand the concept of professionalism any longer. One such example involves a young attorney who was suspended because he "sent a nude picture of the deceased party in a wrongful death action he was defending to a colleague with disparaging comments" (Hull, 2012, p. 272). However, the problem can also be as simple as calling in sick and then posting pictures of oneself at a party or baseball game. Some pertinent examples for college students include the recent graduate who lost her job offer with Cisco for a Tweet and another who took to Quora for advice as to which job should be taken (Uber or Zenefits) (Popkin, 2009). When the CEO of 


\section{Issues in Information Systems}

Volume 20, Issue 4, pp. 157-166, 2019

Zenefits saw the con of his company was it is not a "buzzword like Uber" he rescinded his offer of employment (Dowdy, 2015, para. 3).

What one says on social media may be deleted, but not before it goes viral or has been downloaded by someone for posterity. Nothing online ever truly goes away. Therefore, individuals lose cases, do not get into graduate school, lose jobs, and lose opportunities (Bell, 2018; Price, 2016). Author Jon Acuff warns that your social media site is your present-day resume (Dowdy, 2015). Whether your privacy settings are set, your material can still be shared by others. Seventy percent $(70 \%)$ of human resource managers are now using one's social media presence to screen candidates (O'Brien, 2018). Most are looking to determine "why" they should hire someone (58 percent), but a few are looking for "why not" to hire (22 percent) a prospective candidate (CareerBuilder, 2018). Interestingly, forty-seven percent (47\%) of employers are less likely to call a prospect if they cannot find them online and twenty percent (20\%) said they expect prospects to have an online presence (CareerBuilder, 2018). The more important finding was that eightyfour percent (84\%) said online reputations will impact candidates' in the hiring process "all or most of the time during the next five years" (BestColleges.com, n.d., para. 5).

But, it is not just job candidates that need to be concerned; employers are also reviewing the social media of their current employees (48 percent) (CareerBuilder, 2018). With regard to posts, be careful and conscientious about business matters. As an example, the Karl Knauz Motors Inc. (Case No. 13-CA-46452) decision issued September 28,2011 , will be discussed briefly. One can learn what speech is protected and what is not. In this case, the National Labor Relations Board (NLRB), had to consider posts that a salesman at a car dealership made to his personal Facebook. One post was about lousy food at a dealership sales event. The other post was about an accident at a "sister" dealership. The issue boiled down to was the firing over the lousy food or the accident comment. An Administrative Law Judge (ALJ) heard the case and determined the comments about the lousy food (hot dogs) was covered and protected under the National Labor Relations Act (NLRA) as a viable complaint about the employer "there may have been some customers who were turned off by the food offerings at the event and either did not purchase a car because of it or gave the salesperson a lowering (sic) rating..." ("Finding certain Facebook," 2011, para. 7). The ALJ found differently on the accident comment; it was not a protected or concerted activity. The key to this decision is that Section 7 of the NLRA does not protect actions as described or "individu[al] gripes not involving the terms and conditions of employment or, if about work, gripes about a manager that are not addressed to coworkers..." (Patrick, 2012, para. 6.). One must then watch what one says about your employer in posts. Thus, it is important to understand what millennials believe about their "rights" and how they are utilizing social media.

\section{RESEARCH METHODOLOGY}

A survey was constructed to find out more information about a student/employee views and opinions about social media and their rights when utilizing such sites. The survey was administered through SurveyMonkey to students at three different universities, one private and two public institutions. Two hundred and nineteen (219) surveys were collected. The surveys were administered over a year long period. Students received extra credit or homework credit in their course for completing the survey.

The survey instrument included 51 total questions. This research breaks the data into subgroups based on age, gender, race, year in college, and major. This research focuses on how the subgroups viewed different social media questions. These addressed whether the person had a social media presence, what types of activities they were involved in online, if they felt their privacy on social media was a protected "Civil Rights," and if schools and/or employers have a right to see and/or take action for what students/employees post. "Yes/No" questions, open-ended response, categorical response, and Likert scale ( 1 - strongly disagree to 5 - strongly agree) questions were utilized.

SPSS was used to conduct the statistical analysis. The responses were then divided into subgroups based on age, gender, race, year in college, and major. Using the participant's responses, the means and standard deviations were calculated for each subgroup. Chi-Square tests for Independence were conducted to see if any of the subgroups responded differently when asked the same question. 
The questionnaire asked about the participant's social media presence. The questions ranged from what sites they utilized, how often and how long the participant stayed online, and their belief about their social media presence being protected. Table 1 provides sample questions.

Table 1. Sample Questions

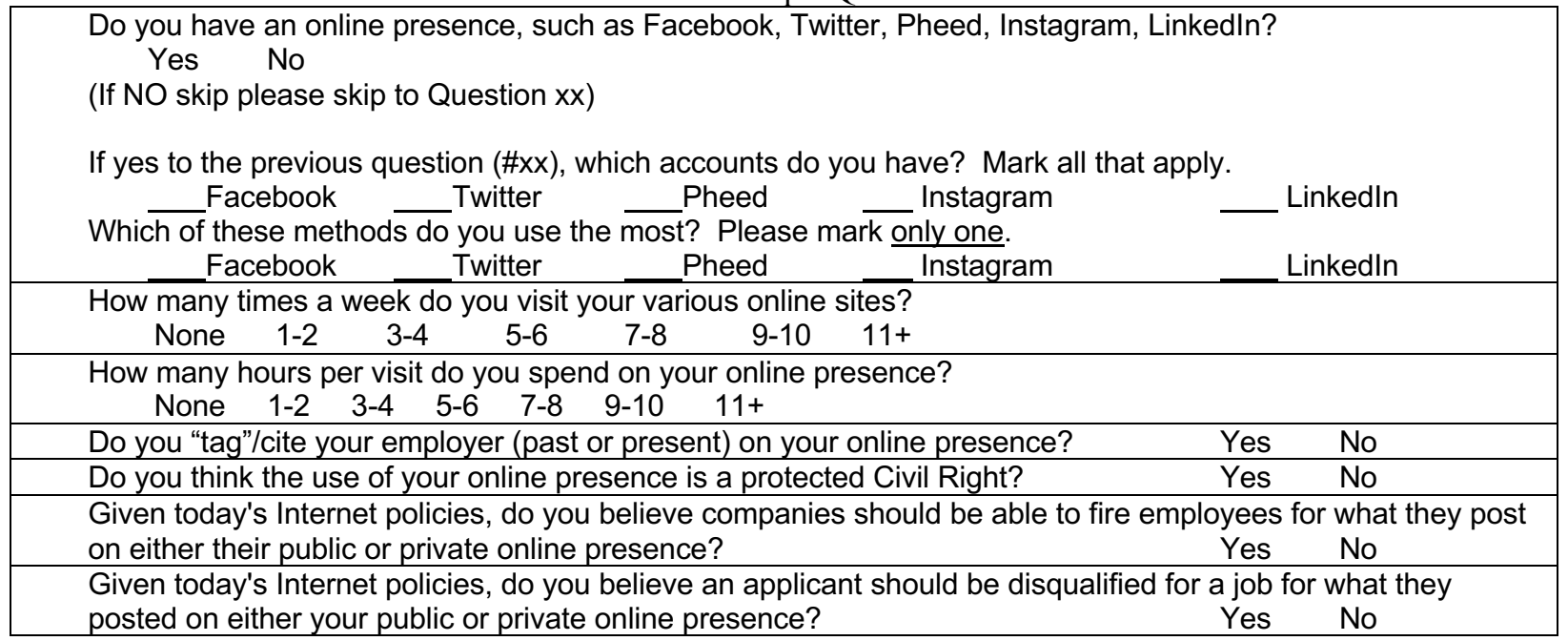

\section{RESULTS}

One of the first questions asked the participants how they utilized their social media presence. Ninety percent (90\%) reported they use it to keep in touch with old friends and family, fifty-four percent (54\%) use it to make new friends, and sixteen percent (16\%) use it to see how many "friends" they can get. Of the respondents, seventy-seven percent (77\%) post photos, thirty-six percent (36\%) post videos, and sixty-six percent $(66 \%)$ post comments. In addition, fifty-four percent (54\%) use it for e-mail, forty percent (40\%) chat or instant message, and twenty-two percent (22\%) use social media as their address or contact book. Further, twenty-nine percent (29\%) played games, nineteen percent (19\%) filled out surveys, eighteen percent (18\%) would take quizzes, and sixteen percent (16\%) would "Like" websites for updates and coupons. Surprisingly, nine percent (9\%) use it to find "significant others."

With regard to professional interests, thirty-three percent (33\%) use social media for research, and twenty-four percent (24\%) for networking with common interest groups. The research found that twenty-six percent (26\%) reported they posted a resume for a classified ad or job search, and twenty percent (20\%) use it for personal promotion. A Likert scale was utilized when the participants were asked if they felt social media was a useful networking tool. The average response was 4.18 , with a standard deviation of .07 , which says the participants strongly think their social media presence is and can be a useful networking tool which can help build "social capital." All of these results are in line with previous findings on social media use and provide an opportunity to further discuss what to do with your social media presence.

H1: With regard to the demographic subgroups, there is a difference in what cites they prefer to post to.

Ninety-five percent (95\%) of the participants posted on Facebook, seventy-one percent (71\%) on Instagram, sixtynine percent (69\%) on Twitter, and forty-nine percent (49\%) on LinkedIn. When testing to see if any of the subgroups had a preference, the only subgroup that was statistically different was race $(\mathrm{p}$-value $=.00)$. African-Americans posted more on Instagram and LinkedIn, Asians tended to post more on Facebook, and Caucasians liked to use Twitter. These findings are in alignment with those found by other researchers.

H2: With regard to the demographic subgroups, there is a difference between how many times a person visits the social media cites per week. 


\section{Issues in Information Systems}

Volume 20, Issue 4, pp. 157-166, 2019

H3: With regard to the demographic subgroups, there is a difference between how much time a person spends per visit.

The participants were surveyed as to how many times a week they visited their social media sites and how long they spent per visit. Fifty-five percent (55\%) reported visiting their sites 11 or more times per week, ten percent $(10 \%)$ visit 9-10 times per week, eight percent (8\%) visit 5-8 times per week, eleven percent (11\%) visit 3-4 times per week, eight percent ( $8 \%$ ) visit $1-2$ times per week, and last, a half of a percent $(.5 \%)$ do not check their social media sites each week. The participants then responded to how many hours they spent on each visit. Eight percent (8\%) spend less than an hour each visit, fifty-seven percent (57\%) spend 1-2 hours each visit, sixteen percent (16\%) spend 3-4 hours per visit, nine percent (9\%) spend 5-6 hours per visit, four percent (4\%) spend 7-8 hours per visit, two percent (2\%) spend 9-10 hours per visit, and last, four percent (4\%) spend 11 or more hours per visit. Concerning how many times per week the participant visited their social media sites, the only statistical difference found within the demographic subgroups was based on age. The study found that those aged 18-20 years old visited nine or more times per week, those aged 21-25 visited 11 or more times per week, those aged 26-30 visited 1-4 times per week, those aged 31-40 either visited 1-2 or 5-6 times per week, those aged 41-50 visited 1-2 times per week, and surprisingly, those aged 51-60 visited 1-4 times per week ( $\mathrm{p}$-value $=.01$ ). With regard to the demographic subgroups, there were no statistical differences based on the time the participants spent per visit.

H4: With regard to the demographic subgroups, there is a difference in those who cite/tag their employers on their person social media sites.

The participants were asked if they "tag/cite" their employers within their social media sites. Thirty-one percent (31\%) "tag/cite" their employers. Concerning "tagging or citing" employers, there were statistical differences. Marketing, management, and computer information systems majors were more likely to "tag/cite" employers than any of the other majors ( $\mathrm{p}$-value $=.00$ ). No other differences were found for the other subgroups.

H5: With regard to the demographic subgroups, there is a difference between who chooses to make their personal sites public/private

H6: With regard to the demographic subgroups, there is a difference between who believes their privacy online is a protected "civil right"

The researchers then changed gears to ask questions about privacy and "Civil Rights" issues. Forty-three percent $(43 \%)$ of the participants reported their social media presence was public and sixty-three percent $(63 \%)$ reported it being private. The total is greater than 100 percent because some participants reported having both a public and a private social media presence. When examining the demographic subgroups, surprisingly, more females had their social media sites set to private and more males tended to have theirs set to public (p-value $=.01$ ). No other differences were found for the other subgroups. Concerning their "protected Civil Rights," more Freshman and Sophomores thought their online presence was a protected Civil Right" than any other year in college (p-value $=.02)$. No other differences were found for the other subgroups.

H7: With regard to the demographic subgroups, there is a difference in the opinion of whether employers should be able to fire employees for what they post publicly/privately online.

H8: With regard to the demographic subgroups, there is a difference in those who believe an employer should be able to view a job candidate's private social media presence as a condition of hiring.

The researchers were also interested in the opinions/perceptions of the participants with regard to employment/selection issues, such as employer monitoring, and employment disqualification based one's social media postings or remarks. When asked if the participant's future employer would look at their public page, ninety-five percent $(95 \%)$ said they thought employers would look at their public sites. Statistically, there were no differences with regard to the demographic subgroups. When asked, "Do you believe potential employers should be able to require you to show them your private page as a condition of being hired or admitted," only forty-three percent (43\%) said "yes." The only statistically significant subgroup difference was gender. More females said "no" and more males said "yes" ( $p$-value $=.01)$. No other differences were found for the other subgroups. 
H9: With regard to the demographic subgroups, there is a difference in those who believe employers should be able to fire employees for what they post online publicly/privately.

H10: With regard to the demographic subgroups, there is a difference in those who believe students should be able to removed from a college program for what they post online publicly/privately.

H11: With regard to the demographic subgroups, there is a difference in those who believe job candidates should be disqualified from a job search for what they post online publicly/privately.

When asked, "Given today's Internet policies, do you believe companies should be able to fire employees for what they post on either their public or private online presence," sixty percent $(60 \%)$ said "yes." Here statistically significant differences were found based on race, year in college, and major. More Caucasians said "yes" as opposed to more African-Americans and Asians saying "no" (p-value = .00). More Juniors and Seniors said "yes;" whereas, more Freshmen and Sophomores said "no" (p-value $=.03)$. Also, more business administration majors said "yes" while the other majors said "no" ( $\mathrm{p}$-value $=.01)$. No other differences were found for the other subgroups. When asked, "Given today's Internet policies, do you believe one should be able to be removed from a college program (e.g., Education/Social Work) for what they posted on either their public or private online presence," thirty-eight percent $(38 \%)$ said "yes." Here, statistically speaking more women than men agreed ( $\mathrm{p}$-value $=.01)$. No other differences were found for the other subgroups. When asked, "Given today's Internet policies, do you believe an applicant should be disqualified for a job for what they posted on either your public or private online presence," fifty-two percent (52\%) said "yes." No other differences were found for the subgroups.

H12: With regard to the demographic subgroups, there is a difference in those who believe employers should be able to monitor and/or fire employees for what they post online publicly/privately.

H13: With regard to the demographic subgroups, there is a difference in those who believe employers should be able to discipline an employee for what they post online publicly/privately if there is a company policy addressing this issue.

H14: With regard to the demographic subgroups, there is a difference in those who believe employers should be able to discipline an employee for what they post online publicly/privately if there is not a company policy addressing this issue.

The last area of the questionnaire shifted to rights of companies to not monitor or fire employees for what they post online on either their private or public pages. Here a Likert scale was utilized. When questioned if companies have the right to monitor an employee's online postings, either public or private, the participant's average response was 3.02 , with a .08 standard deviation. This means the participant's answers averaged around the "Neutral" mark. No statistical differences were found for the demographic subgroups. Concerning the question about whether employers can discipline the employee based on the content they posted online, if the company has an Internet Posting Policy, the participant's average response was 3.42 , with a .07 standard deviation. This means the participant's answers averaged between "Neutral" and "Agree." No other differences were found for the demographic subgroups. Vice versa, when asked if a company does NOT have an Internet Policy, can employers discipline an employee based on

the content they posted online, the participant's average response was 2.58 , with a .08 standard deviation. This means the participant's answers averaged between "Disagree" and "Neutral." There were no statistical differences in the demographic subgroups.

The findings from this study are in alignment with the research and do lead into the important discussion of what "this" all means. Based on the findings, many individuals, including millennials already understand the "state" of social media.

\section{CONCLUSION}

The "Rules of Engagement" are simply "KISS" - Keep It Simple Stupid. "Think" before you post or tweet. One does not want to have a recruiter or employer question one's judgment (Dowdy, 2015).

Here are some rules to consider: 1) posts should not contain anything that is offensive or can be perceived as offensive; 2) be careful with one's "freedom of speech;" 3) can the posts pass the "public versus anonymous" test; 4) post only using one's private Internet providers and avoid using university or company servers; 5) don't lie about your 


\section{Issues in Information Systems}

Volume 20, Issue 4, pp. 157-166, 2019

qualifications; 6) don't "bad mouth" previous employers; 7) don't share confidential employment related secrets; 8) don't post too frequently (CareerBuilder, 2018; O'Brien, 2018; Williams et al., 2012). Also, as employers expect you to have a social presence, it is best not to "turn off" or make private your online presence. Also, while posting too much is a problem; so is posting too little (Thottam, n.d.). These thoughts come from the literature, but are in line with the findings of this research. Millennials do feel that there should be scrutiny for what individuals do while in the workplace or after work when it comes to their social presence. However, they are more lenient when it comes to their time in college; a time when many feel they should be able to express themselves more. What one says online is seen as a "civil right" for them and it should have protections.

In the workplace, one thing everyone needs to remember is that even if you are on your personal e-mail at work, the employer may be able to see it. Along with the right to monitor, listen, and record your calls, employers can monitor your computer usage and what you are doing may be seen with monitoring software and may not be "private." In fact, employees lose most cases brought based on the issue of privacy at work (Bussing, 2011). Further, don't use work time for personal shopping excursions. Don't use work time to catch up with friends on Facebook and Twitter. Do not "friend" your supervisors so they won't see the embarrassing photos of you show up on other's sites where you are "tagged." Again, these warnings for millennials come from the literature and the results of this study that shows they believe companies should have internet and social media policies and they should be properly enforced. Afterall, they are still using these methods to "like" materials, play games, and connect with others. These are all items which cause viruses on corporate computers and when their social presence is use to create "bad will" for an employer could get them fired. Companies need to ensure millennials understand the corporate policies. They also need to understand how to use social media to their advantage with millennials as these employees can provide a great deal of "good will" with their posting and online habits.

To start, before looking for that next job or college, millennials, and others, should check all Internet search providers by typing one's name in the search bar to see what "pops up." Also, try to delete tags from other people on Facebook and inappropriate Tweets. The problem here is they remain in a search history for an undefined time after deletion (BestColleges.com, n.d.). One must remember that one's social media is now treated as a resume. Lies, mistruths and errors on resumes are not acceptable; thus, the same has come of one's social media presence (Kiser \& Prater, 2002).

Now, after a discussion of what not to do, what should millennials do? Join sites like LinkedIn and "network" in a positive fashion. Join a professional group (BestColleges.com, n.d.). A smart choice for most is something tied to their current job, the job they want, and the alumni group at their college(s). As Dowdy (2015) noted, "Use your social networks to ... network" (para. 9). To get the job and keep the job, keep everything professional - keep your personal Facebook separate from your business Facebook. Another thought for positive impact is to create a "virtual interview of yourself" and post it on YouTube with a link to your resume on LinkedIn (Collins, 2011). Another thought would be to create a blog and successfully Tweet when you are at industry events while in college or participating in a field trip, internship, or global excursion (Collins, 2011). Millennials, and others, should increase their use, which is relatively low (mid- to low 20 percent range), of social media for personal promotion as noted above.

\section{FUTURE RESEARCH}

A limitation of this research is it includes a convenience sample. However, the participants were millennials. There is a need to understand what their current perceptions are of social media and how they utilize it. This research does show differences in attitudes on how millennials and some others view social media based on age, race, major, and level in college. In particular, there were a number of differences based on gender. All of these factors need to be further researched.

The student population surveyed does tend to be more lenient when discussing inappropriate behavior online when it affects one's college career versus one's employment. College is a place of "exploration;" thus, they may think it is also to be more "forgiving" of mistakes. The problem is today's competitive college environment is much less "forgiving." Students do believe one's actions should have consequences with regard to employment. 


\section{Issues in Information Systems}

Volume 20, Issue 4, pp. 157-166, 2019

Future research should be conducted to replicate and move these findings forward. Technology and the methods millennials, and others, use to communicate with each other and businesses are constantly evolving. For example, Snapchat, Vero, Vine, and Hootsuite should be included in future research.

\section{REFERENCES}

American Press Institute. (2015, March 16). How millennials use and control social media. Retrieved May 18, 2019, from http://www.americanpressinstitute.org/publications/reports/survey-research/millennials-social-media/

Bell, J. (2018, August 24). Firing for online behavior. Retrieved May 10, 2019, from https://www.shrm.org/hrtoday/news/hr-magazine/0918/pages/firing-for-online-behavior-.aspx

BestColleges.com. (n.d.). How to manage your online reputation. Retrieved May 23, 2019, from http://www.bestcolleges.com/resources/manage-your-online-reputation/

Bolton, R. N., Parasuraman, A., Hoefnagels, A., Migchels, N., Kabadayi, S., Gruber, T., Loureriro, Y. K., \& Solnet, D. (2013). Understanding Generation Y and their use of social media: A review and research agenda. Journal of Service Management, 24(3), 245-267.

Broderick, R. (2012, August 3). Tuscon executive fired for crazy Chick-fil-A YouTube rant. Retrieved May 23, 2019, from http://www.buzzfeed.com/ryanhatesthis/tuscon-executive-fired-for-crazy-chick-fil-ayoutu\#.dh15g3L9O

Bussing, H. (2011, October 4). Employee privacy - What can employers monitor? HR Examiner. Retrieved May 9, 2019, from http://www.hrexaminer.com/employee-privacy-what-can-employers-monitor/

Careerbuilder.com. (2018, August 9). More than half of employers have found content on social media that caused them NOT to hire a candidate, according to recent CareerBuilder survey. Retrieved May 10, 2019, from http://press.careerbuilder.com/2018-08-09-More-Than-Half-of-Employers-Have-Found-Content-on-SocialMedia-That-Caused-Them-NOT-to-Hire-a-Candidate-According-to-Recent-CareerBuilder-Survey

Cohen, C. J., Fowler, M. Medencia, V. E., \& Rogowski, J. C. (2018, March). Millennials and technology: An overview of usage, news consumption, the future of work, and public policy. Retrieved May 10, 2019, from https://genforwardsurvey.com/assets/uploads/2018/03/GenForward-March-2018-Tech-Report_FINAL.pdf

Collins, A. (2011, September 11). Social media: A double-edged sword. Ag \& Food Employer Guide, 48(7), S26.

DeMers, J. (2017, October). 7 bad workplace habits millennials need to stop making. Entrepreneur. Retrieved May 10, 2019, from https://www.entrepreneur.com/article/301069

Diaz, J., \& Effron, L. (2015, March 25). Former CFO on food stamps after controversial viral video about Chick-filA. Retrieved May 20, 2019, from http://abcnews.go.com/Business/cfo-food-stamps-controversial-viralvideo/story?id=29533695

Dowdy, L. (2015, June 9). Avoid these career-killing social media mistakes. Retrieved May 9, 2019, from http://www.cnbc.com/id/102740402

Employer accused of violating federal labor law by discharging an employee for bashing her boss on Facebook. (2010, November 23). Mondaq Business Briefing. Retrieved January 30, 2012, from Business \& Company Resource Center.

Ethics Resource Center. (2014). National Business Ethics Survey of Social Networkers. Retrieved May 20, 2019, from https://www.ibe.org.uk/userassets/surveys/erc_ethics_and_social_networking.pdf 
Finding certain Facebook activity to be unprotected, NLRB dismisses two charges. (2011, November 14). Mondaq Business Briefing. Retrieved January 30, 2013, from Business \& Company Resource Center.

Fry, R., Igielnik, R., \& Patten, E. (2018, March 16). How millennials today compare with their grandparents 50 years ago. Retrieved May 10, 2019, from https://www.pewresearch.org/fact-tank/2018/03/16/how-millennialscompare-with-their-grandparents/

Hull, H. G. (2012, Winter). Legal ethics for the millennials: Avoiding the compromise of integrity. University of Missouri - Kansas City Law Review, 80, 271-286.

Janicke-Bowles, S. H., Narayan, A., \& Seng, A. (2018, Fall). Social media for good? A survey on millennials inspirational social media use. The Journal of Social Media in Society, 7(2), 120-140.

Kiser, S. B., \& Prater, T. (2002, Spring). Lies, Lies, and More Lies. SAM Advanced Management Journal, 672(2), 9-14+.

McCorkindale, T., DiStaso, M. W., \& Sisco, H. F. (2013, Spring). How millennials are engaging and building relationships with organizations on Facebook. The Journal of Social Media in Society, 2(1), 66-87.

Miller, M. B., Hodge, K. H., Brandt, A., \& Schneider, E. A. (2013, Spring). The young and the restless: Gen Y'ers in the workplace! Are you prepared? FDCC Quarterly, 63(3), 226-250.

Moran, K. (2016, January 3). Millennials as digital natives: Myths and realities. Retrieved May 10, 2019, from https://nngroup.com/articles/millennials-digital-natives/

National Chamber Foundation. (2012). The millennial generation: Research Review. Retrieved June 1, 2015, from http://www.uschamberfoundation.org/millennial-generation-research-review

Nielsen. (2014, February 26). Millennials: Technology = social connection. Retrieved June 5, 2015, from http://www.nielsen.com/us/en/insights/news/2014/millennials-technology-social-connection.html

O'Brien, S. (2018, August 10). Employers check your social media before hiring. Many of them find reasons not to offer you a job. Retrieved May 10, 2019, from https://www.cnbc.com/2018/08/10/digital-dirt-may-nix-thatjob-you-were-counting-on-getting.html

Patrick, M. (2012, March). Social media and employers: Friends or enemies? Utah Business, 26(3), 32.

Peterson, H. (2015, March 31). A former CFO is now unemployed and living on food stamps after his rant against Chick-fil-A went viral. Business Insider. Retrieved June 26, 2015, from http://www.businessinsider.com/excfo-unemployed-after-chick-fil-a-rant-2015-3

Pew Research Center. (2018, February 5). Social media fact sheet. Retrieved May 10, 2019, from https://www.pewinternet.org/fact-sheet/social-media/

Popkin, H. (2009, March 27). Getting the skinny on Twitter's 'Cisco Fatty.' Retrieved March 6, 2015, from http://www.nbcnews.com/id/29901380/\#.VVT6yvlViko

Prater, T. \& Smith, K. (2011, June). Underlying Factors Contributing to Presenteeism and Absenteeism. Journal of Business \& Economic Research, 9(6), 1-14.

Price, L. (2016, July 8). 20 tales of employees who were fired because of social media posts. People. Retrieved May 10, 2019, from https://people.com/celebrity/employees-who-were-fired-because-of-social-mediaposts/ 


\section{Issues in Information Systems}

Volume 20, Issue 4, pp. 157-166, 2019

Thottam, I. (n.d.). These social media mistakes can actually disqualify you from a job. Retrieved May 10, 2019, from https://www.monster.com/career-advice/article/these-social-media-mistakes-can-actually-disqualifyyou-from-a-job

Verschoor, C. C. (2013, August). Ethical behavior differs among generations. Strategic Finance, 95(2), 11-12,14.

Warner, R. (2013, April 2). Who wastes more time at work: Millennials, Gen X'ers, or boomers? Huffington Post. Retrieved May 10, 2019, from https://www.huffpost.com/entry/who-wastes-more-time-at-w_b_2618279

Williams, D. L., Crittenden, V. L., Keo, T., \& McCarty, P. (2012). The use of social media: An exploratory study of usage among digital natives. Journal of Public Affairs, 12(2), 127-136.

York, J. (2017, March 8). The millennial expectation of technology in the workplace. Retrieved May 10, 2019, from https://www.paycom.com/resources/blog/millennial-expectation-of-tech-in-the-workplace 